\title{
透析患者における大腸手術症例の検討
}

\begin{tabular}{|c|c|c|c|c|c|c|c|}
\hline 原 & 全 & 中 鳥 & 明 & 中 J & 川 & 彦 & 林 \\
\hline 田 & 茂 & 河 & 達 自 & 本 & 田 & & 淵之上 昌平 \\
\hline 岡 & 慧 & 高 橋 & 公 & 東 & 間 & & 阿 岸 \\
\hline
\end{tabular}

太田 和夫

東京女子医科大学腎藏病総合医療センター外科

(平成 1 年 3 月 8 日受付)

key words：慢性腎不全, 透析患者, 大腸癌, 大腸良性疾患, 外科手術

〈要旨〉

透析患者の増加と透析期間の長期化にともない, 透析患者に対する外科的治療の機会も増してきている. 消化器系 疾患についても同様の傾向があり，その手術適応の拡大につれて多くの施設で透析患者に対する消化器系手術が行わ れるようになっている.

今回, 我々は当科において外科的治療を行った透析患者の大腸病変について検討した。

昭和 58 年 1 月より昭和 62 年 12 月までに, 当科において施行された消化器系手術は 133 例であり, このうち 25 例 （19\%）が大腸疾患に対する手術であった。年齢は 35 歳から 70 歳 (平均 53.7 歳)，透析期間は 4 日から 16 年（平均 5 年 11 か月）であり, 13 例が良性疾患, 12 例が悪性腫瘍に対する手術であった.

良性疾患の内訳は，4 例が潰瘍および虚血性腸炎による出血，3 例が S 状結腸穿孔であり，良性ポリープおよびイ レウスが各 2 例ずつ認められた，虚血性腸炎および潰瘍は回盲部と直腸に集中して認められ，穿孔例は 3 例とも $\mathrm{S}$ 状 結腸に発生した。

組織学的には, 良性疾患 13 例中 8 例に虚血性の変化を認めたが, アミロイド沈着が証明されたのは 1 例のみであっ た.

悪性疾患 12 例中 11 例が大腸癌であり，4 例が早期癌であった。治癒切除は 11 例中 8 例（73\%）に施行された. Stage I 〜 I の腸癌に対する手術予後は良好であり, 心筋梗塞により死亡した 1 例を除き全例生存している. 大腸癌発見の契機として, 潜血便・血便が 8 例, 血中 CEA 值が術前より高值を示す例が 5 例に認められ, 透析患 者に対する積極的な下部消化管の検索が必要であると考えられた。

\section{Colon and rectal surgery in hemodialysis patients}

Tamotsu Tojimbara, M. D., Ichiroh Nakajima, M. D., Yoshihiko Nakagawa, M. D., Taketoshi Hayashi, M. D., Tatsuo Kawai, M. D., Hiroshi Honda, M. D., Syohei Fuchinoue, M. D., Satoshi Teraoka, M. D., Kota Takahashi, M. D., Hiroshi Toma, M. D., Tetsuzo Agishi, M. D., Kazuo Ota, M. D.

Department of Surgery, Kidney Center, Tokyo Women's Medical College

As the number of patients with chronic renal failure treated by dialysis has been steadily increasing, surgical treatments for such patients have also increased.

In the five years from January 1983 to December 1987, a total of 133 operations for digestive diseases were performed in patients undergoing hemodialysis at the Kidney Center, Tokyo Women's Medical College Hospital.

Twenty-five of the 133 operations (19\%) were performed for colorectal disease.

Thirteen out of 25 cases had benign diseases : ulcer and/or ischemic colitis in four, perforation of the sigmoid colon in three, benign polyps in two and ileus in two. Ischemic colitis and ulcer were found mainly in the cecum and rectum.

唐仁原 全 東京女子医科大学腎臓病総合医療センター外 科 7162 新宿区河田町 8-1 (03-353-8111)
In 8 of the 13 benign cases, ischemic changes were recognized histologically, however, amyloid deposition 
was found in only one case.

Eleven cases of malignant tumor had colorectal carcinomas, Eight of these patients (73\%) underwent curative surgery. Satisfying results were obtained in Stage I- II colorectal patients who underwent surgical treatment.

Colorectal cancer was indicated by melena or occult blood in the stool in 8 cases and increased of serum CEA in 5 .

These results emphasize the importance of active examinations of the lower intestinal tract in patients receiving hemodialysis.

\section{緒言}

透析患者数の増加と透析期間の長期化に伴い慢性腎不 全患者に対する外科的治療の機会も増してきている．消 化器系疾患についても同様の傾向があり, uremic ulcer ${ }^{1)}$ や悪性腫瘍 ${ }^{2}$ のために透析患者に対する消化器系手術 は，近年，多くの施設で行われるようになっている。

透析患者における消化器系疾患のなかでも, 大腸病変 は上部消化管の病変に比べその頻度も低く ${ }^{3}$ 報告も少な いが, 消化器手術例の増加に伴い大腸病変の外科的治療 の機会も増えつつある。

今回，我々は当科において外科的治療を行った大腸病 変について検討を加えたので報告する.

\section{対象}

対象は, 昭和 58 年 1 月より昭和 62 年 12 月までに当科 において透析患者に行われた消化器系手術 133 例中, 大 腸疾患に対して行われた手術症例 25 例 (19\%)である (虫 垂切除術は除く).

年齢は 35 歳から 70 歳, 平均 54.3 歳, 透析歴は 4 日か ら 16 年であり平均 5 年 10 か月であった（表 1 ).

これら 25 症例を良性疾患・悪性腫瘍に大別し，各々の 透析歷別発生頻度, 発生部位, 発見の契機, 術式, 予後,
組織所見について検討した。

さらに，アミロイド沈着の有無を検索するために良性 疾患 13 例中 8 例において, 切除標本に対し Congo-red 染色を行った。

\section{成績}

1. 疾患の種類

透析患者に対する, 133 例の消化器系手術のうち 25 例 (19\%)が大腸病変に対する手術であった。疾患別に見る と (図 1)，12 例 (48\%) が悪性腫瘍であり，良性疾患は 13 例（52\%）であった。

良性疾患の内訳は，4 例（16\%）が潰瘍抒よび虚血性 病変， 3 例 $(12 \%)$ が $\mathrm{S}$ 字状結腸穿孔であり，良性ポリー プ・イレウスが各 2 例（8％）に認められた。その他の 2 例は, 腸間膜動脈血栓による全結腸壊死とクローン病 であった。

悪性疾患においては，症例 25 の Schnitzler 転移例を 除き全例原発性悪性腫瘍であった。

2 . 透析歴別の症例数

症例数を透析歴別に比較すると(図 2 ), 透析導入後 3 年以内が 10 例と最も多いが，透析歴 $7 \sim 9$ 年および $10 \sim 12$ 年の症例も 5 例ずつ存在した。一方，良性・悪性

表 1 透析患者に扔ける大腸手術症例

(昭和 58 年 1 月～昭和 62 年 12 月)

\begin{tabular}{|c|c|c|c|c|c|c|c|c|c|c|c|}
\hline \multicolumn{6}{|c|}{ 良性疾患 } & \multicolumn{6}{|c|}{ 覀性疾患 } \\
\hline 症例 & 年齢 & - 性 & 原疾患 & 透析歴 & 診 断 & 症例 & 年䔥 & - 性 & 原疾患 & 透析歴 & 部 位 \\
\hline 1 & 69 & 男 & DM & 不定期 & 虚血性腸炎 & 14 & 35 & 男 & CGN & 9 か月 & $\mathrm{S}$ 状結腸癌 \\
\hline 2 & 39 & 女 & $\mathrm{DM}$ & 9 年 & イレウス & 15 & 39 & 男 & $\mathrm{CGN}$ & 1 年 6 か月 & $S$ 状結腸癌 \\
\hline 3 & 51 & 男 & CGN & 導入前 & 直腸潰瘍 (虚血性) & 16 & 70 & 男 & $\mathrm{CGN}$ & 5 か月 & 直腸癌 \\
\hline 4 & 38 & 女 & SLE & 4 日 & 全結腸壊死 & 17 & 70 & 男 & CGN & 7 か月 & 上行結腸癌 \\
\hline 5 & 57 & 男 & DM & 1 か月 & 大腸ポリープ & 18 & 55 & 女 & $\mathrm{CGN}$ & 3 年 2 か月 & 直腸癌 \\
\hline 6 & 57 & 男 & PCK & 6 年 & $\mathrm{S}$ 状結腸破裂 & 19 & 43 & 女 & $\mathrm{CGN}$ & 1 か月 & 横行結腸癌 \\
\hline 7 & 53 & 男 & CGN & 8 年 2 か月 & $\prime \prime$ & 20 & 60 & 男 & CGN & 1 年 5 か月 & 直腸癌 \\
\hline 8 & 61 & 男 & TBC & 9 年 & 虚血性腸炎 & 21 & 61 & 男 & $\mathrm{TBC}$ & 9 年 1 か月 & 直腸癌 \\
\hline 9 & 60 & 女 & CGN & 6 年 4 か月 & $" \prime$ & 22 & 67 & 男 & $\mathrm{DM}$ & 9 年 9 か月 & 下行結腸癌 \\
\hline 10 & 65 & 男 & $\mathrm{DM}$ & 11 年 & クローン病 & 23 & 69 & 男 & CGN & 5 年 1 か月 & $S$ 状結腸癌 \\
\hline 11 & 53 & 男 & CGN & 16 年 & $\mathrm{S}$ 状結腸破裂 & 24 & 48 & 女 & CGN & 9 年 9 か月 & 横行結腸癌 \\
\hline 12 & 50 & 女 & CGN & 11年 5 か月 & イレウス & 25 & 49 & 男 & PCK & 1 年 7 か月 & 胃癌腹膜播種 \\
\hline 13 & 39 & 男 & CGN & 13年 7 か月 & 大腸ポリープ & & & & & & \\
\hline
\end{tabular}

CGN : 慢性系球体腎炎 $\mathrm{TBC}$ : 腎結核 $\mathrm{DM}$ ：糖尿病性腎症 PCK：多発性軎胞腎 
表 2 良性疾患に対する手術

\begin{tabular}{|c|c|c|c|c|c|c|c|c|}
\hline 症例 & \multicolumn{2}{|c|}{ 年齢・性 } & 原疾患 & 透析歴 & 診 断 & 術 式 & 合併症 & 予 後 \\
\hline 1 & 69 & 男 & $\mathrm{DM}$ & 不定期 & 虚血性腸炎 & 回盲部切除 & & 生 存 \\
\hline 2 & 39 & 女 & $\mathrm{DM}$ & 9 年 & イレウス & 上行結腸切除 & & 11 \\
\hline 3 & 51 & 男 & $\mathrm{CGN}$ & 導入前 & 直腸潰瘍（虚血性） & 止血 & & "1 \\
\hline 4 & 38 & 女 & SLE & 4 日 & 全結腸壊死 & 全結腸切除 & $\begin{array}{l}\text { 上部消化管出血 } \\
\text { DIC }\end{array}$ & 死亡32日 \\
\hline 5 & 57 & 男 & $\mathrm{DM}$ & 1 か月 & 大腸ポリープ & ポリープ切除 & & 生 存 \\
\hline 6 & 57 & 男 & PCK & 6 年 & S 状結腸穿孔 & $\mathrm{S}$ 状結腸切除 & 腹膜炎 & $\prime \prime$ \\
\hline 7 & 53 & 男 & $\mathrm{CGN}$ & 8 年 2 か月 & $\prime \prime$ & $\prime \prime$ & 肝硬変 & 死亡 1 年 \\
\hline 8 & 61 & 男 & $\mathrm{TBC}$ & 9 年 & 虚血性腸炎 & 人工肛門造設 & 不整脈・肺炎 & 生 存 \\
\hline 9 & 60 & 女 & $\mathrm{CGN}$ & 6 年 4 か月 & $\prime \prime$ & 右半結腸切除 & & $\prime \prime$ \\
\hline 10 & 65 & 男 & $\mathrm{DM}$ & 11年 & クローン病 & 回盲部切除 & 肝障害 & 11 \\
\hline 11 & 53 & 男 & $\mathrm{CGN}$ & 16 年 & S 状結腸穿孔 & 人工肛門造設 & & $\prime \prime$ \\
\hline 12 & 50 & 女 & $\mathrm{CGN}$ & 11年 5 か月 & イレウス & イレウス解除 & & $\prime \prime$ \\
\hline 13 & 39 & 男 & $\mathrm{CGN}$ & 13年 7 か月 & 大腸ポリープ & ポリープ切除 & & " \\
\hline
\end{tabular}

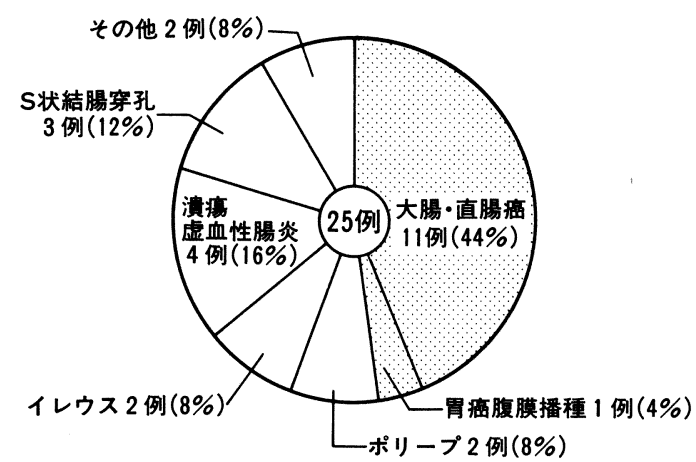

図 1 疾患別にみた大腸手術症例

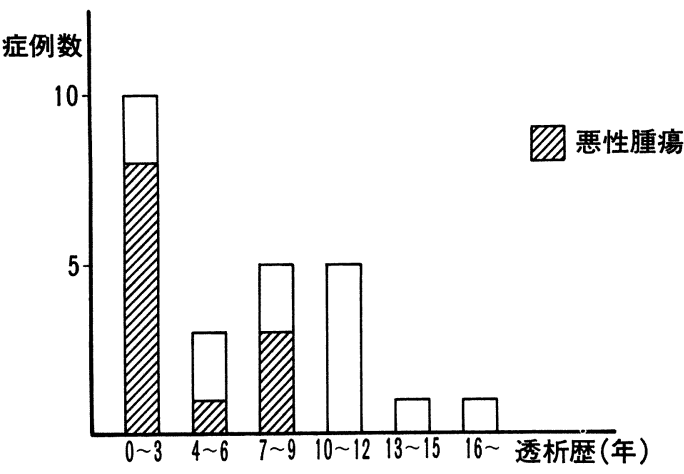

図 2 大腸手術症例の透析歴

疾患別にみると, 悪性腫瘍は全例透析開始後 9 年以内に みられ 3 年以内に最も多いのに対し, 良性疾患はいずれ の透析期間においても認められた。

3 . 各疾患の発生部位

図 3 は各疾患の発生部位を示したものであるが，原発 性悪性腫瘍 11 例中 7 例 (64\%) が S 状結腸あるいは直腸
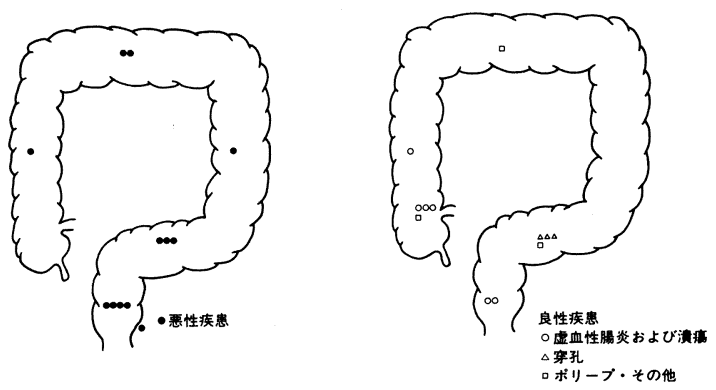

図 3 良悪性疾患別の発生部位

に認められた。

一方良性疾患では，虚血性腸炎および潰瘍が回盲部と 直腸に集中して認められ，穿孔例は 3 例とも $\mathrm{S}$ 状結腸に 発生した。

4。良性疾患に対する手術

良性疾患に対する大腸手術症例は 13 例 (52\%) であっ た（表 2).

i ) 術式

術式として腸切除が 7 例, 人工肛門造設が 2 例, ポリー プ切除が 2 例，イレウス解除・止血が各 1 例ずつ行われ ている.

ii）合併症および予後

死亡例は 2 例であり, 症例 4 の全結腸壊死症例は術前 より全身状態不良であり術後上部消化管出血・DICをき たし術後 32 日目に死亡した. 症例 7 は術前より存在した 肝硬変のため術後 1 年目に死亡した. その他の症例は全 例生存しており，手術予後は良好であった。

iii）組織学的所見

良性疾患 13 例中虚血性腸炎あるいは虚血によると考 えられる潰瘍・壊死が 5 例に認められ, 症例 2 のイレウ 不例にも組織学的には虚血性の変化が認められた。 
表 3 組織学的所見

\begin{tabular}{|c|c|c|c|c|}
\hline 症例 & 診 断 & $\begin{array}{l}\text { 組織学的 } \\
\text { 診 断 }\end{array}$ & 虚血性変化 & $\begin{array}{l}\text { アミロイド } \\
\text { 沈 着 }\end{array}$ \\
\hline 1 & 虚血性腸炎 & 虚血性腸炎 & + & - \\
\hline 2 & イレウス & & + & - \\
\hline 4 & 全結腸壊死 & 虚血性腸炎 & + & - \\
\hline 5 & 大腸ポリープ & 腺管腺腫 & & \\
\hline 6 & S 状結腸穿孔 & & - & - \\
\hline 7 & "1 & & + & - \\
\hline 8 & 虚血性腸炎 & 虚血性腸炎 & + & - \\
\hline 9 & "1 & $n$ & + & - \\
\hline 10 & クローン病 & クローン病 & - & \\
\hline 11 & S 状結腸穿孔 & & + & + \\
\hline 13 & 大腸ポリープ & 腺管腺腫 & & \\
\hline
\end{tabular}

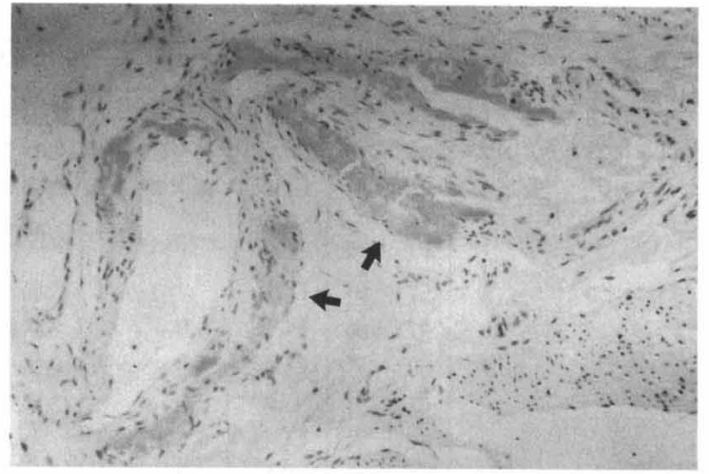

図 4 症例11の病理組織像 (Congo-red 染色 $\times 100)$

腸管の全層にわたり，動脈壁の内膜より中膜にかけ て Congo-red 染色陽性（个部）所見を認める.

表 4 悪性疾患に対する手術

\begin{tabular}{|c|c|c|c|c|c|c|c|c|c|}
\hline 症例 & 年齢 & 性 & 診 断 & stage & 深達度 & 術 式 & 根治性 & 合併症 & 予後 \\
\hline 14 & 35 & 男 & $\mathrm{S}$ 状結腸癌 & I & $\mathrm{sm}$ & $S$ 状結腸切除 & 絶対治療切除 & 肝機能障害 & 生 存 \\
\hline 15 & 39 & 男 & ") & I & $\mathrm{sm}$ & "I & $\prime \prime$ & & "1 \\
\hline 16 & 70 & 男 & 直腸癌 & I & $\mathrm{m}$ & 低位前方切除 & " & & " \\
\hline 17 & 70 & 男 & 上行結腸癌 & III & $\mathrm{s}$ & 右半結腸切除 & 相対治瘾切除 & 肺炎 - ARDS & 1) 死亡33日 \\
\hline 18 & 55 & 女 & 直腸癌 & V & si & Mile's ope & 相対非治痛切除 & & 生 存 \\
\hline 19 & 43 & 女 & 横行結腸癌 & II & s & 横行結腸切除 & 絶対治瘺切除 & & " \\
\hline 20 & 60 & 男 & 直腸癌 & IV & $\mathrm{s}$ & 低位前方切除 & 相対非治㽷切除 & & $\begin{array}{l}{ }^{2)} \text { 死 亡 } \\
2 \text { 年 } 8 \text { か月 }\end{array}$ \\
\hline 21 & 61 & 男 & " & II & $\mathrm{s}$ & "n & 1 & 肺炎 - 不整脈 & 生 存 \\
\hline 22 & 67 & 男 & 下行結腸癌 & II & $\mathrm{s}$ & 左半結腸切除 & 相対治瘜切除 & 心筋梗塞 & 3) 死亡45日 \\
\hline 23 & 69 & 男 & S 状結腸癌 & II & ss & $\mathrm{S}$ 状結腸切除 & 絶対治㾤切除 & & 生 存 \\
\hline 24 & 48 & 女 & 横行結腸癌 & I & $\mathrm{m}$ & 横行結腸切除 & $\prime \prime$ & 肝機能障害 & $n$ \\
\hline 25 & 49 & 男 & 胃癌腹膜播種 & & & 人工肛門 & & 心筋症 & 3) 死亡10日 \\
\hline
\end{tabular}

CGN : 慢性系球体腎炎 TBC：腎結核 DM：糖尿病性腎症 PCK：多発性霍胞腎 ${ }^{1)}$ 呼吸不全, ${ }^{2}$ 肝転移, ${ }^{3)}$ 心不全

大腸ポリープ症例は 2 例とも tubular adenoma で あった（表 3 ).

Congo-red 染色を行った 8 例中, 明らかなアミロイド 沈着を認めたのは症例 11 のみであった（図 4 ).

5 ，悪性疾患に対する手術

覀性腫瘍に対する手術は 12 例 (48\%) に施行された(表 $1,4)$.このうち大腸癌症例 11 例につき, 腫瘍の進行 度・手術の根治性・予後・発見の契機について検討した。

\section{i ）大腸癌の進行度}

大腸癌の進行度は, Stage I が 4 例, Stage II が 4 例, Stage III・IV・Vが各々 1 例ずつであった.

ii）大腸癌手術の根治性

絶対治癒切除を施行し得た症例は 11 例中 6 例（55\%） であり, 相対治癒切除を含めると 8 例 (73\%) であった. iii）大腸癌手術例の予後

死亡例は 3 例であり, 症例 17 は肺炎のため, 症例 20 は 肝転移により術後 2 年 8 か月目に死亡した. 症例 22 は術 前より存在した心不全の悪化により,術後 45 日目に死亡 した (表 4 ).

iv）大腸癌発見の契機抢よび CEA 值

大腸癌の初発症状としては，血便が 5 例 (45\%) と最 も多く, 潜血便の精査により診断された症例が 3 例存在 した.

また大腸癌の腫瘍マーカーである血中癌胎児性抗原 (CEA) が，術前より高值を示す症例が 5 例 (45\%) に認 められた（表 5 ).

\section{考察}

1859 年の Treit $\mathrm{z}^{11}$ による報告を嗃矢として，いわゆる uremic ulcer に関する記載は多く ${ }^{4,5)}$ ，その病変は消化管 
表 5 大腸癌発見の契機

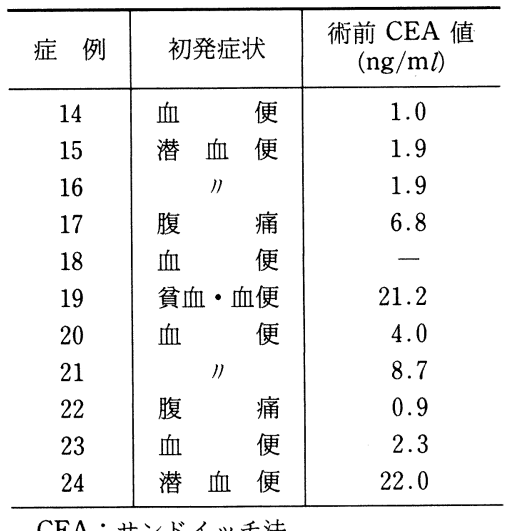

CEA：サンドイッチ法

(正常値 $2.9 \mathrm{ng} / \mathrm{m} l$ 以下)

全体に様々な状態で存在するといわれる。しかしその発 生機序については，まだ不明な点も多い.

Mason $ら^{6)}$ も, 腎不全状態においては出血性病変が消 化管内で最も多く認められる所見であり, 特に潰瘍性あ るいは壊死性病変は回腸と結腸に最も多く見られると述 べている.

今回我々の成績では, 大腸手術症例 25 例中良性疾患に 対する手術が 13 例 (52\%) であり，なかでも虚血性腸炎 あるいは虚血性の変化を伴った潰瘍・壊死が 5 例に認め られた。さらに症例 2 のイレウス例，および $\mathrm{S}$ 状結腸破 裂例 3 例中 2 例にも, 組織学的には粘膜の凝固壊死, 粘 膜下浮腫, 粘膜固有層・筋層の変性壊死といつた虚血性 の変化を認めた，すなわち良性疾患 13 例中 8 例 $(62 \%)$ に虚血性の変化が存在していた。

透析患者は, K制限による摄取繊維の不足や水分制限, alumigel 服用のために便秘を来たしやすく，さらに透析

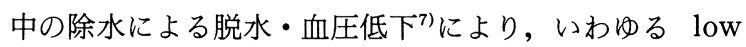
-flow state ${ }^{8)}$ の状態にある. また透析患者に共通してみ られる高血圧, 脂質代謝異常, 貧血, 2 次性副甲状腺機 能六進症などは，いずれも動脈硬化症のリスクファク ターであり, 消化管の支配血管への動脈硬化性病変の影 響も無視できない9

Friedell ら ${ }^{8}$ は, 大腸のなかでも盲腸は最も虚血の影響 を受けやすいと述べており，我々の症例でも虚血性腸炎 は回盲部に集中して認められた. S 状結腸破裂の 3 例は, いずれも alumigel を服用し慢性の便秘症状を訴えてい た.このうち 2 例は浣腸後に発症しており，十分な注意 が必要と考えられた。

さらに近年, 透析患者における全身性アミロイドーシ スが注目されており，手根管をはじめ全身組織へのアミ ロイド沈着が証明されている ${ }^{10,11}$. 今回, 大腸虚血性病変
に対するアミロイドの影響を明らかにするために 8 症例 に Congo-red 染色を施行した. 結果は表 3 のごとく, 明 らかなアミロイド沈着を認めた例は症例 11 の 1 例のみ であり, 大腸虚血性疾患に対するアミロイドーシスの影 響は少ないと考えられた。

一方，透析患者における悪性腫場の発生頻度の高さは 以前より指摘されており ${ }^{2}$, わが国においては, その約半 数が消化管に発生している3).

近年, 我が国における大腸癌の増加傾向が指摘されて おり,透析患者においても結腸および直腸/肛門の悪性腫 瘍発生率は全消化器悪性腫瘍の約 $22 \%$ を占め, 正常人の 約 2 倍と報告されている ${ }^{3)}$.

その原因として, 慢性腎不全状態における種々の発癌

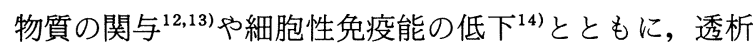
患者の食生活（高蛋白・高脂肪・低繊維） ${ }^{15}$ ，便秘，腸蠕 動の低下などが挙げられている。

今回の成績では，大腸手術症例 25 例中 11 例 (48\%) が大腸癌に対する手術であり，11 例中 4 例が早期癌で あった. その発見時期は, 良性疾患がいずれの透析期間 にもみられるのに対し, 悪性腫瘍は全例透析開始後 9 年 以内に発見され 11 例中 7 例 $(64 \%)$ が透析導入後 3 年以 内であった. Linder $ら^{16)}$ も, 透析患者の悪性腫瘍の大部 分が透析導入後 2 年以内に発見されたと報告しており, 透析患者の細胞性免疫能が透析導入直前に著明に低下 し, 数か月以内にある程度改善されるが正常域までには 復しないという曽和ら ${ }^{14)}$ の報告を考えると興味深い.

根治性を検討すると 11 例中 6 例 (55\%) に, 絶対治癒 切除を施行しており，相対治癒切除を含めると 8 例 （73\%）であった。

手術例の予後は比較的良好であり, 治癒切除を行った 8 例中死亡例は 1 例であるのに対し, 非治癒切除例 3 例 中 2 例が死亡している. 非治癒切除例の死亡例は，いず れも Stage IIIないし Stage IVであり, Stage I〜IIの 大腸癌に対しては, 安全に治癒切除が可能であると考え られた。

大腸癌発見の契機としては，潜血便・血便が 8 例を占 め, CEA が異常值を示す例が 5 例に認められた。透析患 者においては, 腎不全状態による出血傾向, 透析中の抗 凝固剂の使用など出血性病変の存在が早期に顕性化され る可能性があり, 大腸病変が存在すれば腎機能正常者よ り発見の機会は多いとも考えられる。通常, 血液透析患 者は週 3 回医療機関を訪れており, 特に悪性腫瘍の発見 を遅らせてはならない. 今回の成績よりみても, 便潜血・ 腫瘍マーカーの検索を含めた積極的な定期検査の実施に より Stage I 〜 IIの段階で悪性腫瘍を発見することが， 透析患者の大腸悪性疾患の手術成績・予後の改善に最も 
重要であると考えられた。

まとめ

1. 透析患者の大腸手術症例 25 中 13 例（52\%）が良 性疾患， 12 例 ( $48 \%$ ) が悪性腫瘍に対する手術であった。

2. Congo-red 染色を行った良性疾患 8 例中アミロイ ドの沈着を認めたのは 1 例のみであった。

3 . 大腸癌 11 例中 4 例が早期癌であり，8例（73\%） に治癒切除が施行された.

4. 大腸癌発見の契機として, 潜血便・血便が 8 例に 認められ, 血中 CEA 值が高值を示す例が 5 例に認めら れた。

5. Stage I 〜II の大腸癌に対する手術予後は良好で あり，悪性腫瘍の早期発見のために透析患者に対する積 極的な下部消化管の検索が必要と考えられた。

\section{文献}

1) Treitz $R$ : Über urämish Darmaffektionen. Pragervjschr prakt Heilk 64 : 143, 1859

2) Matas JJ, Simmons RL, Kjellstrand CM, Buselmeier TJ, Najarian JS: Increased incidence of malignancy during chronic renal failure. Lancet i : 883-886, 1975

3) Ota K, Yamashita N, Suzuki T, Agishi T : Malignant tumors in dialysis patients. Proc EDTA 18 : 724-730, 1981

4) Ja'ffe RH, Laing DR : Changes of the digestive tract in uremia. Arch Intern Med $53: 851-864$, 1934

5) Adams PL, Rutsky EA, Rostand SG, Hann SY : Lower gastrointestinal tract dysfunction in patients receiving longterm hemodialysis : Arch Intern Med $142:$ 303-306, 1982

6) Mason EE : Gastrointestinal lesions occuring in uremia. Ann Intern Med 37 : 96-105, 1952
7) Aubia J, Lloveras J, Munne' A, Solsona J, Orfila MA, Riambau E, Serrano S, Llorach M : Ischemic colitis in chronic uremia. Nephron $29: 146-150$, 1981

8) Mark L Friedell : Cecal necrosis in the dialysis -dependent patient. Am Surg 51 : 621-623, 1985

9) Nicholls AJ, Catto GRD, Edward N, Engeset J : Accelerated atherosclerosis in long-term dialysis and renal trans plant patients ; factor or fiction? Lancet i : 276-278, 1980

10) Gejyo F, Yamada S, Odani S : A new form of amyloid protein associated with chronic hemodialysis was identified as $\beta_{2}$-microglobulin. Biochem Biophys. ResCommun 129 : 1092-1032, 1985

11）佐々木優里, 太田和夫, 堀田 茂, 寺岡 慧, 江良 和雄, 久保和雄, 山口 裕, 笠島 武: 透析患者に おける二次性アミロイドーシス 透析会誌 21 : 407-411, 1988

12) Massry SG, Kopple JD : Uremic toxins: What are they? How are they identified? Semin Nephrol $3: 263-264,1983$

13) Kjellstrand C, Matas A, Cosio F : Are malignancies increased in uremia and dialysis? Proc 8th Int Congr Nephrol Athen s. p. 1217, 1981

14）曽和信正：血液透析療法に導入した慢性腎不全患者 に打ける細胞性免疫能の経時的変化に関する研究 透析会誌 $20 ： 975-984,1987$

15）柴田昌雄, 中川成之輔, 前田貞亮: 今透析食を考え る, 臨床透析 $1: 53,1985$

16) Linder A, Farewell VT, Sherrard DJ : High incidnce of neoplasia in uremic patients recieving long -term dialysis. Nephron 27 : 292-296, 1981 